\title{
Erratum to: A cost evaluation methodology for surgical technologies
}

Imad Ismail • Sandrine Wolff • Agnes Gronfier •

Didier Mutter $\cdot$ Lee L. Swanström

Published online: 10 January 2015

(c) Springer Science+Business Media New York 2015

Erratum to: Surg Endosc

DOI 10.1007/s00464-014-3929-4

The Family Name of Lee L. Swantröm is incorrect. The correct spelling is Lee L. Swanström.

The online version of the original article can be found under doi:10. 1007/s00464-014-3929-4.

I. Ismail · S. Wolff

University of Strasbourg, BETA, Strasbourg Cedex, France

I. Ismail $(\bowtie) \cdot$ A. Gronfier - L. L. Swanström

IHU Strasbourg, S/c IRCAD, 1, place de l'Hôpital,

67091 Strasbourg Cedex, France

e-mail: imad.ismail@ihu-strasbourg.eu

D. Mutter

Strasbourg University Hospital, Strasbourg Cedex, France 